\title{
Odontogenic keratocysts in gorlin-goltz syndrome: how to manage?
}

\author{
Khalfi Lahcen ${ }^{1 *}$, Hamama jalal ${ }^{1}$, Fiqhi Mohamed Kamal ${ }^{2}$, N'diaye Abibou ${ }^{2}$, Ribag Yassamina ${ }^{3}$ and Elkhatib Karim ${ }^{4}$ \\ ${ }^{1}$ Department of Stomatology and Maxillofacial Surgery, 'Mohammed V' Teaching Armed Forces Hospital- Morocco \\ ${ }^{2}$ Resident Doctor, 'Mohammed V' Teaching Armed Forces Hospital- Morocco \\ ${ }^{3}$ Consultant Doctor, 'Mohammed V' Teaching Armed Forces Hospital- Morocco \\ ${ }^{4}$ Professor (Head), 'Mohammed V' Teaching Armed Forces Hospital- Morocco
}

\begin{abstract}
Odontogenic keratocysts is a frequent manifestation of Gorlin-Goltz syndrome and can be its first sign, mainly in young patients. There are two methods for the treatment of KCOT, a conservative and an aggressive. A more careful approach for the syndrome is needed as there is high chance of malignant changes owing to improper management of the syndrome.
\end{abstract}

\section{Introduction}

Gorlin-Goltz syndrome is an autosomal dominant disorder characterized by a predisposition to neoplasms and other developmental abnormalities [1]. In 1960, Robert James Gorlin and William Goltz described Gorlin-Goltz syndrome as a condition, comprising the principle triad of multiple Basal Cell Carcinoma, odontogenic keratocysts (OKC) and skeletal anomalies [2-3]. This syndrome has numerous names as basal cell nevus syndrome, multiple BCC syndrome and fifth phacomatosis [4]. The tumor suppressor gene called Patched (PTCH), located in the 9q22.3 chromosome, has been identified as cause of Gorlin-Goltz syndrome [5-6]. Mutations in this gene results in loss of control of several genes known to play a role in organogenesis, carcinogenesis and odontogenesis thus resulting in the development of GGS [7-10]. The prevalence is about 1/60000 live births, and it has both sporadic and familial incidence [11]. This syndrome affects both male and female equally and are seen during the first, second, third decades of life [12]. In this manuscript we report a case of Gorlin-Goltz syndrome where we focused on the management of treatment protocol of odontogenic keratocysts with review of literature.

\section{Case report}

A 22-year-old female patient reported to our Department of Oral Maxillofacial. From a dentist as her orthopantomogram showed multiple well-defined radiolucency (Figure 1). One lesion was in left ramus with the impacted 38 tooth, of about $2 \mathrm{~cm} \times 2 \mathrm{~cm}$ and another lesion was in the right en the left body of mandible from 47 to 45 , of about $4 \mathrm{~cm} \times 2 \mathrm{~cm}$ and the last one was in the left body o from 37 to 36 of about $3 \mathrm{~cm} \times 2 \mathrm{~cm}$. She had reported to the dentist with a chief complaint of swelling in the left side of lower jaws. It had started as a small swelling that increased in size over 10 months.

The patient was the fifth child of non-consanguineous parents there were no familial history of similar lesions. Clinical examination revealed dysmorphic facial features including mild macrocephaly, frontal bossing, hypertelorism, multiple nevi of size on the face and suspected nodular lesions on the left lower eyelid and on right side of the forhead (Figure 2).

Other examinations were also performed which included skull radiograph showed calcification of falx cerebri (Figure 3) and bridging of sella turcica. Under general anesthesia, extended ward's incision was placed in the left ramus region. Cyst enucleation and surgical removal of 38 was performed. On the right body of the mandible, a crevicular incision with relieving incision was placed from 48 to 45 and cyst enucleation was performed. Carnoy's solution was applied on the exposed bony walls with preservation of the inferior alveolar neurovascular bundle in the cystic cavities for $3 \mathrm{~min}$, and charring effect was achieved. The cystic cavities were then irrigated thoroughly with normal saline and closure done with 3-0 Vicryl.

Simultaneously, the tumor on the forehead and on the lower eyelid were removed, the defect consecutive was repaired by local flap (Figure 4).

The specimens were sent for histopathological examination. Histopathological report revealed and confirmed the presence KCOT and basal cell carcinoma for our patient. Based on clinical, radiographic and microscopic data, the diagnosis of Gorlin-Goltz syndrome was established. New bone formation sites were identified in the threemonth radiological follow-up. The patient is being followed-up for past 6 months on a regular basis without evidence of any recurrence. In addition, molecular genetic studies confirmed PTCH 1 germline mutations. The patient and his parents are aware of the importance of regular examination.

*Correspondence to: Khalfi Lahcen, Department of Stomatology and Maxillofacial Surgery, 'Mohammed V' Teaching Armed Forces HospitalMorocco, E-mail: khalfi.1@hotmail.fr

Key words: Basal Cell nevus syndrome, odontogenic cysts, Gorlin's Syndrome

Received: February 15, 2018; Accepted: February 17, 2018; Published: February 21,2018 


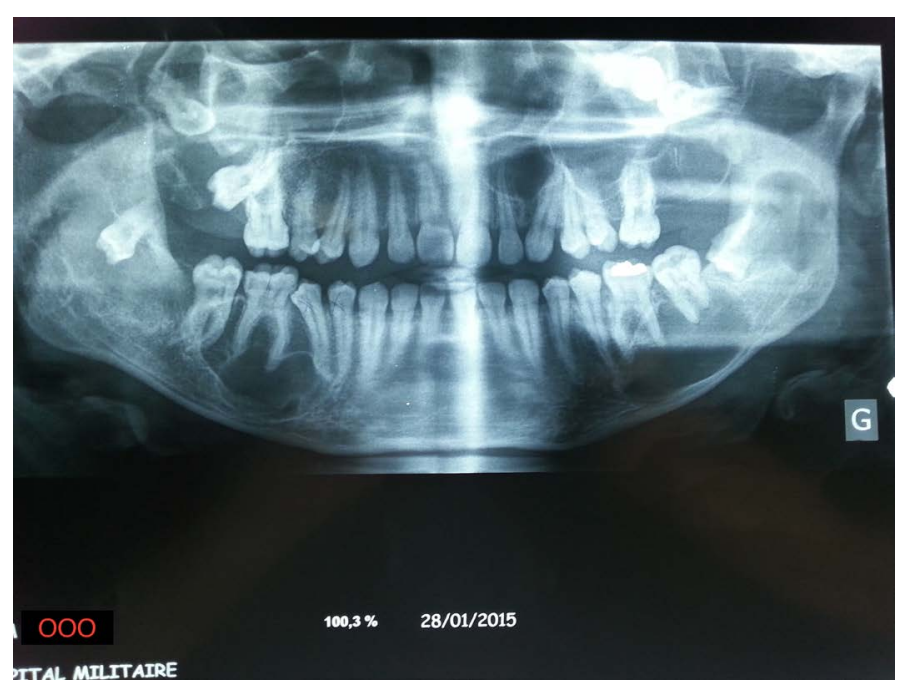

Figure 1. Preoperative Orthopantographic showed multiple well-defined radiolucency

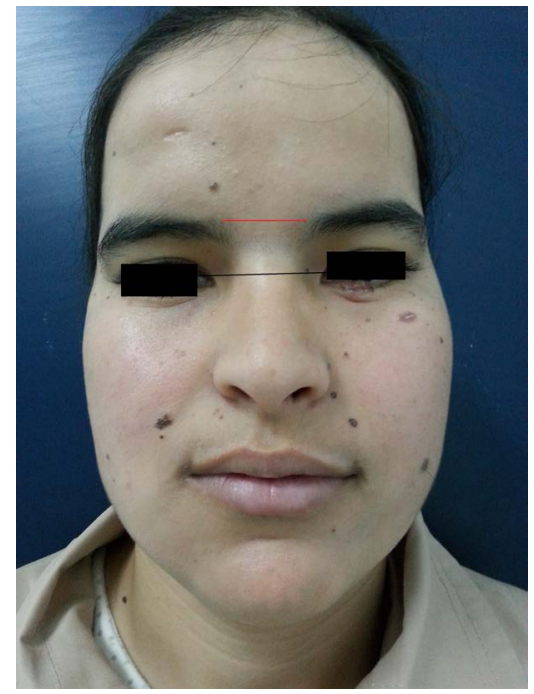

Figure 2. Facial appearance of patient showed dysmorphic facial features, including relative macrocephaly and ocular hypertelorism and basal cell carcinoma on left lower eyelid

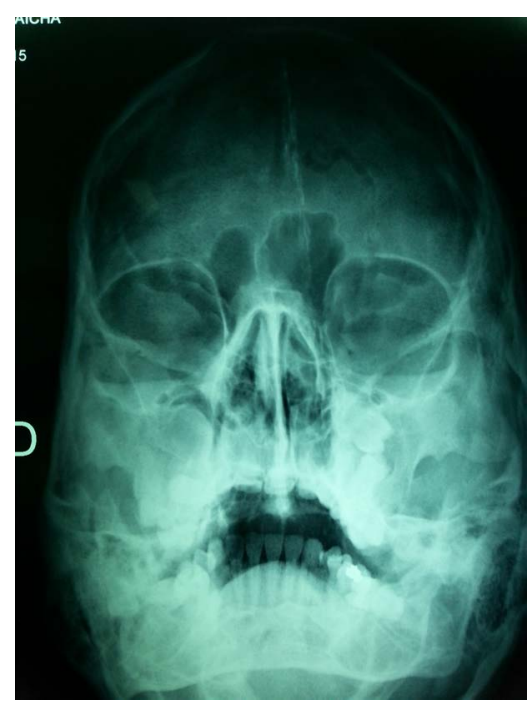

Figure 3. Calcification of falx cerebri

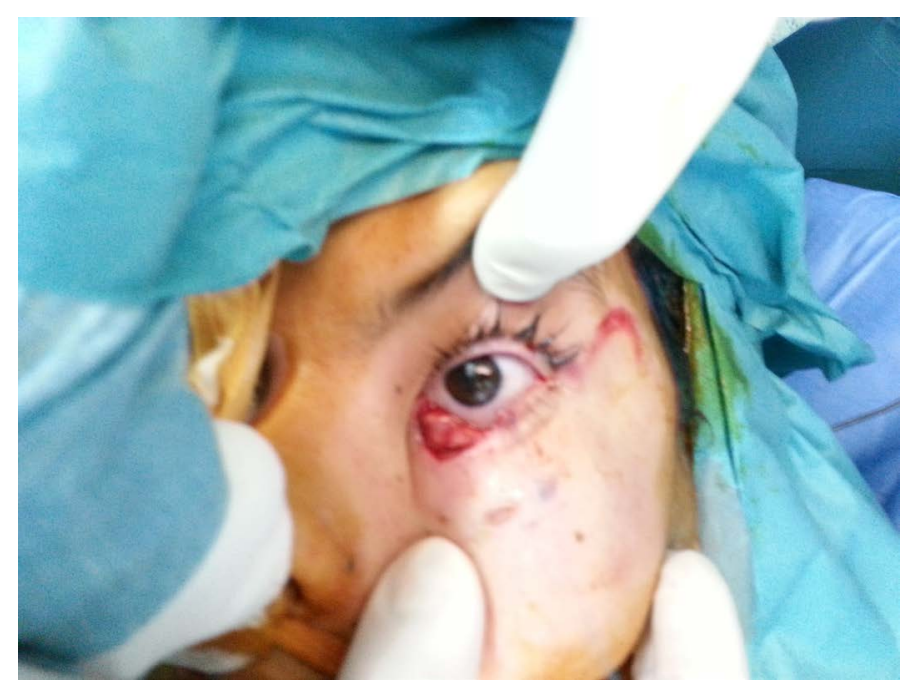

Figure 4. Per-operatory view showing excision of basl cell carcinoma

\section{Discussion}

According to the clinical criteria of Kimonis et al. [13] (Table 1), the diagnostic criteria of NBCCS require the presence of two major, or one major and two minor criteria. KCOTs are among the most consistent and common features of Gorlin-Goltz syndrome. They are fet alound in 65 to $100 \%$ of affected individuals [14]. Clinically, the lesions are characterized by aggressive growth and a tendency to recur after surgical treatment. The mandible is involved more frequently than the maxilla and the posterior regions are the most commonly affected sites [15].

There are two methods for the treatment of KCOT, a conservative and an aggressive. In the conservative method, simple enucleation with or without curettage and marsupialization are suggested. Aggressive methods include peripheral ostectomy, chemical curettage with Carnoy's solution, and resection [16]. Radical interventions as enucleation with shaving of surrounding bone or sometime resection might contribute to preventing recurrences and to improve the prognosis $[16,17]$.

In the following cases the aggressive method should be applied:

1) When KCOT recurs after a conservative method 2) in cases of multilocular (multi lobular) aggressive intraosseous KCOT; 3 ) in a diagnosed KCOT exhibiting particularly aggressive clinical behavior (eg. growth, destruction of adjacent tissues) that should require resection as the initial surgical treatment [18]. In our case, as far as KCOT is mulilocular without aggressive behavior, a conservative method was appropriate.

Although some authors believe that simple enucleation might be the most appropriate conservative method for the treatment of KCOT [18]. Application of Carnoy's solution into the cyst cavity for 3 min after enucleation results in a lower rate of recurrence $(0-2.5 \%)$ without any damage to the inferior alveolar nerve [19,20]. Although benign, the recurrence rate after excision of KCOT is high, ranging from $12 \%$ to $62.5 \%$, that's due to a higher rate of proliferation of the epithelial lining [ 21,22]. Regular follow-up by a multi-specialists team should be offered.An annual dental panoramic radiograph is usually suggested between the ages of 8 and 40 years to aid in monitoring the recurrence or development of new KCOT [23,24]. Moreover, it is of great importance to make a dermatological examination every 3-6 months with removal of basal cell nevus showing evidence of growth, 
Table 1. Criteria of Gorlin-Goltz syndrome

\begin{tabular}{|l|l|}
\hline Major or 1 major and 2 minor criteria should be satisfied for positive diagnosis. \\
\hline Major criteria & $\begin{array}{l}\text { 1. More than two BCCs or one BCC under the } \\
\text { age of } 20 \text { years }\end{array}$ \\
\hline $\begin{array}{l}\text { 2. Histologically proven odontogenic keratocyst } \\
\text { of the jaw }\end{array}$ \\
\hline $\begin{array}{l}\text { 3. Three or more cutaneous palmar or plantar } \\
\text { pits }\end{array}$ \\
\hline \begin{tabular}{l} 
4. Bifid, fused or markedly splayed ribs \\
\hline $\begin{array}{l}\text { 5. First degree relative with nevoid basal cell } \\
\text { carcinomas }\end{array}$
\end{tabular} \\
$\begin{array}{l}\text { 1. Proven macrocephaly, after adjustment for } \\
\text { height }\end{array}$ \\
$\begin{array}{l}\text { 2. One of the several orofacial congenital } \\
\text { malformations: cleft lip or palate, frontal } \\
\text { bossing, 'coarse face', moderate or severe } \\
\text { hypertelorism }\end{array}$ \\
\hline $\begin{array}{l}\text { This consists of any one of the } \\
\text { following features }\end{array}$ & $\begin{array}{l}\text { deformity, marked pectus deformity, marked } \\
\text { syndactyly of the digits }\end{array}$ \\
\hline $\begin{array}{l}\text { 4. Radiological abnormalities: bridging of } \\
\text { the sella turcica, vertebral anomalies such as } \\
\text { hemivertebrae, fusion or elongation of the } \\
\text { vertebral bodies, modeling defects of the hands } \\
\text { and feet, or flame shaped lucencies of the hands } \\
\text { or feet }\end{array}$ \\
\hline $\begin{array}{l}5 . \text { Ovarian fibroma } \\
\text { 6. Medulloblastoma }\end{array}$ \\
\hline
\end{tabular}

ulceration or hemorrhage. The patient must prevent harmful exposure to ultraviolet and ionizing radiations that increase the risk of developing basal cell carcinoma.

\section{Acknowledgements}

The authors are grateful to the patient and their family for their contribution to this article. Written consent for publication was obtained from the patient's parent.

\section{Competing interests}

The authors declare that they have no competing interests.

\section{References}

1. Yamamoto K, Yoshihashi H, Furuya N, Adachi M, Ito S, et al. (2009) Further delineation of 9q22 deletion syndrome associated with basal cell nevus (Gorlin) syndrome: report of two cases and review of the literature. Congenit Anom (Kyoto) 49: 8-14. [Crossref]

2. Gorlin RJ, Goltz RW (1960) Multiple nevoid basal-cell epithelioma, jaw cysts and bifid rib. A syndrome. $N$ Engl J Med 262: 908-912. [Crossref]

3. Deepa MS, Paul R, Balan A (2003) Gorlin Goltz syndrome: A review. J Indian Acad Oral Med Radiol 15: 203-209.

4. Lo Muzio L (2008) Nevoid basal cell carcinoma syndrome (Gorlin syndrome). Orphanet J Rare Dis 3: 32. [Crossref]

5. Gorlin RJ (1999) Nevoid basal cell carcinoma (Gorlin) syndrome: unanswered issues. J Lab Clin Med 134: 551-552. [Crossref]

6. Yang X, Pfeiffer RM, Goldstein AM (2006) Influence of glutathione-S-transferase (GSTM1, GSTP1, GSTT1) and cytochrome p450 (CYP1A1, CYP2D6) polymorphism on numbers of basal cell carcinomas (BCCs) in families with the naevoid basal cell carcinoma syndrome. J Med Genet 43: e1-e16. [Crossref]
7. Acocella A, Sacco R, Bertolai R, Sacco N (2009) Genetic and clinicopathologic aspects of Gorlin-Goltz syndrome (NBCCS): presentation of two case reports and literature review. Minerva Stomatol 58: 43-53. [Crossref]

8. Donatsky O, Hjørting-Hansen E (1980) Recurrence of the odontogenic keratocyst in 13 patients with the nevoid basal cell carcinoma syndrome. A 6-year follow-up. Int J Oral Surg 9: 173-179. [Crossref]

9. Dowling PA, Fleming P, Saunders ID, Gorlin RJ, Napier SS (2000) Odontogenic keratocysts in a 5-year-old: Initial manifestations of nevoid basal cell carcinoma syndrome. Pediatr Dent 22: 53-55. [Crossref]

10. Soekarman D, Fryns JP, Casaer P, Van Den Berghe H (1991) Increased head circumference and facial cleft as presenting signs of the nevoid basal-cell carcinoma syndrome. Genet Couns 2: 157-162. [Crossref]

11. Bakaeen G, Rajab LD, Sawair FA, Hamdan MA, Dallal ND (2004) Nevoid basal cell carcinoma syndrome: a review of the literature and a report of a case. Int $J$ Paediatr Dent 14: 279-287. [Crossref]

12. Evans DG, Farndon PA, Burnell LD, Gattamaneni HR, Birch JM (1991) The incidence of Gorlin syndrome in 173 consecutive cases of medulloblastoma. Br J Cancer 64: 959-961. [Crossref]

13. Kimonis VE, Goldstein AM, Pastakia B, Yang ML, Kase R, et al. (1997) Clinical manifestations in 105 persons with nevoid basal cell carcinoma syndrome. Am J Med Genet 69: 299-308. [Crossref]

14. Sun LS, Li XF, Li TJ (2008) PTCH and SMO gene alterations in keratocystic odontogenic tumors. $J$ Dent Res 87: 575-579. [Crossref]

15. González-Alva P, Tanaka A, Oku Y, Yoshizawa D, Itoh S, et al. (2008) Keratocystic odontogenic tumor: a retrospective study of 183 cases. J Oral Sci 50: 205-212. [Crossref]

16. Kolokythas A, Fernandes RP, Pazoki A, Ord RA (2007) Odontogenic keratocyst: to decompress or not to decompress? A comparative study of decompression and enucleation versus resection/peripheral ostectomy. J Oral Maxillofac Surg 65: 640644. [Crossref]

17. Kuroyanagi N, Sakuma H, Miyabe S, Machida J, Kaetsu A, et al. (2009) Prognostic factors for keratocystic odontogenic tumor (odontogenic keratocyst): analysis of clinico-pathologic and immunohistochemical findings in cysts treated by enucleation. $J$ Oral Pathol Med 38: 386-392. [Crossref]

18. Tolstunov L, Treasure $\mathrm{T}$ (2008) Surgical treatment algorithm for odontogenic keratocyst: combined treatment of odontogenic keratocyst and mandibular defect with marsupialization, enucleation, iliac crest bone graft, and dental implants. J Oral Maxillofac Surg 66: 1025-1036. [Crossref]

19. Voorsmit RA, Stoelinga PJ, van Haelst UJ (1981) The management of keratocysts. $J$ Maxillofac Surg 9: 228-236. [Crossref]

20. Stoelinga PJ (2005) The treatment of odontogenic keratocysts by excision of the overlying, attached mucosa, enucleation, and treatment of the bony defect with carnoy solution. J Oral Maxillofac Surg 63: 1662-1666. [Crossref]

21. Dominguez FV, Keszler A (1988) Comparative study of keratocysts, associated and non-associated with nevoid basal cell carcinoma syndrome. J Oral Pathol 17: 39-42. [Crossref]

22. el Murtadi A, Grehan D, Toner M, McCartan BE (1996) Proliferating cell nuclear antigen staining in syndrome and nonsyndrome odontogenic keratocysts. Oral Surg Oral Med Oral Pathol Oral Radiol Endod 81: 217-220. [Crossref]

23. Farndon PA, Del Mastro RG, Evans DG, Kilpatrick MW (1992) Location of gene for Gorlin syndrome. Lancet 339: 581-582. [Crossref]

24. Kopera D, Cerroni L, Fink-Puches R, Kerl H (1996) Different treatment modalities for the management of a patient with the nevoid basal cell carcinoma syndrome. $J$ Am Acad Dermatol 34: 937-939. [Crossref]

Copyright: (C2018 Lahcen K. This is an open-access article distributed under the terms of the Creative Commons Attribution License, which permits unrestricted use, distribution, and reproduction in any medium, provided the original author and source are credited. 